\title{
Invited review: Milk lactose-Current status and future challenges in dairy cattle
}

\author{
A. Costa, ${ }^{1}$ N. Lopez-Villalobos, ${ }^{2}$ N. W. Sneddon, ${ }^{2 *}$ L. Shalloo, ${ }^{3}$ M. Franzoi, ${ }^{1}$ M. De Marchi, ${ }^{1}$ and M. Penasa ${ }^{1} \dagger$ \\ ${ }^{1}$ Department of Agronomy, Food, Natural Resources, Animals and Environment, University of Padova, Viale dell'Università 16, \\ 35020 Legnaro (PD), Italy \\ ${ }^{2}$ School of Agriculture and Environment, Massey University, Private Bag 11 222, Palmerston North 4442, New Zealand \\ ${ }^{3}$ Animal and Grassland Research and Innovation Centre, Teagasc, Moorepark, Fermoy, Co. Cork, P61 C997, Ireland
}

\section{ABSTRACT}

Lactose is the main carbohydrate in mammals' milk, and it is responsible for the osmotic equilibrium between blood and alveolar lumen in the mammary gland. It is the major bovine milk solid, and its synthesis and concentration in milk are affected mainly by udder health and the cow's energy balance and metabolism. Because this milk compound is related to several biological and physiological factors, information on milk lactose in the literature varies from chemical properties to heritability and genetic associations with health traits that may be exploited for breeding purposes. Moreover, lactose contributes to the energy value of milk and is an important ingredient for the food and pharmaceutical industries. Despite this, lactose has seldom been included in milk payment systems, and it has never been used as an indicator trait in selection indices. The interest in lactose has increased in recent years, and a summary of existing information about lactose in the dairy sector would be beneficial for the scientific community and the dairy industry. The present review collects and summarizes knowledge about lactose by covering and linking several aspects of this trait in bovine milk. Finally, perspectives on the use of milk lactose in dairy cattle, especially for selection purposes, are outlined.

Key words: lactose, bovine milk, health trait, breeding, dairy industry

Received November 7, 2018.

Accepted March 15, 2019.

*Present address: Fonterra Research Centre, Dairy Farm Road,

Fitzherbert, Palmerston North 4472, New Zealand.

†Corresponding author: mauro.penasa@unipd.it

\section{INTRODUCTION}

Milk is an energetic animal-derived food, rich in essential fatty acids, vitamins, minerals, amino acids, and oligosaccharides. Among these nutrients, lactose is the main sugar, uniquely found in mammals' milk. Lactose contributes to the energy value of milk, as reported in the formula of Tyrrell and Reid (1965): total energy output $(\mathrm{MJ} / \mathrm{kg})=[0.384 \times$ fat percentage +0.223 $\times$ protein percentage $+0.199 \times$ lactose percentage $0.108] \times$ milk yield $(\mathrm{kg})$.

In bovines, lactose is the major milk solid (Fox et al., 2015), and it is individually recorded in lactating cows almost all over the world under routine evaluation systems. In recent decades, likely due to the increased availability of milk data from infrared predictions, lactose percentage $(\mathbf{L P})$ has been included in scientific studies and reports, together with traditional traits such as milk yield, fat percentage, and protein percentage. Although LP has been considered a low-informative trait for decades due to its low variability, some investigations have reported interesting findings, particularly its negative relationship with SCC. Thus, interest in LP has increased, as has the number of published papers dealing in some manner with lactose (Figure 1). Nevertheless, there is no uniform consensus about the phenotypic and genetic factors affecting LP and lactose yield $(\mathbf{L Y})$. After the optimization of dairy industry efficiency and the application of whey filtration technologies, lactose powder has become a food ingredient with a market demand and value (CLAL, 2018). In spite of this, scientific knowledge about the physiology and variability of lactose is still scarce, because of consensus that this compound is constant in milk and does not affect milk quality and technological properties. However, some studies have demonstrated that a certain informative variation in lactose within and across lactations exists in cattle (Miglior et al., 2007; Alessio et al., 2016; Costa et al., 2018). Therefore, it seems appropriate to provide a clearer, more complete picture for lactose, to 


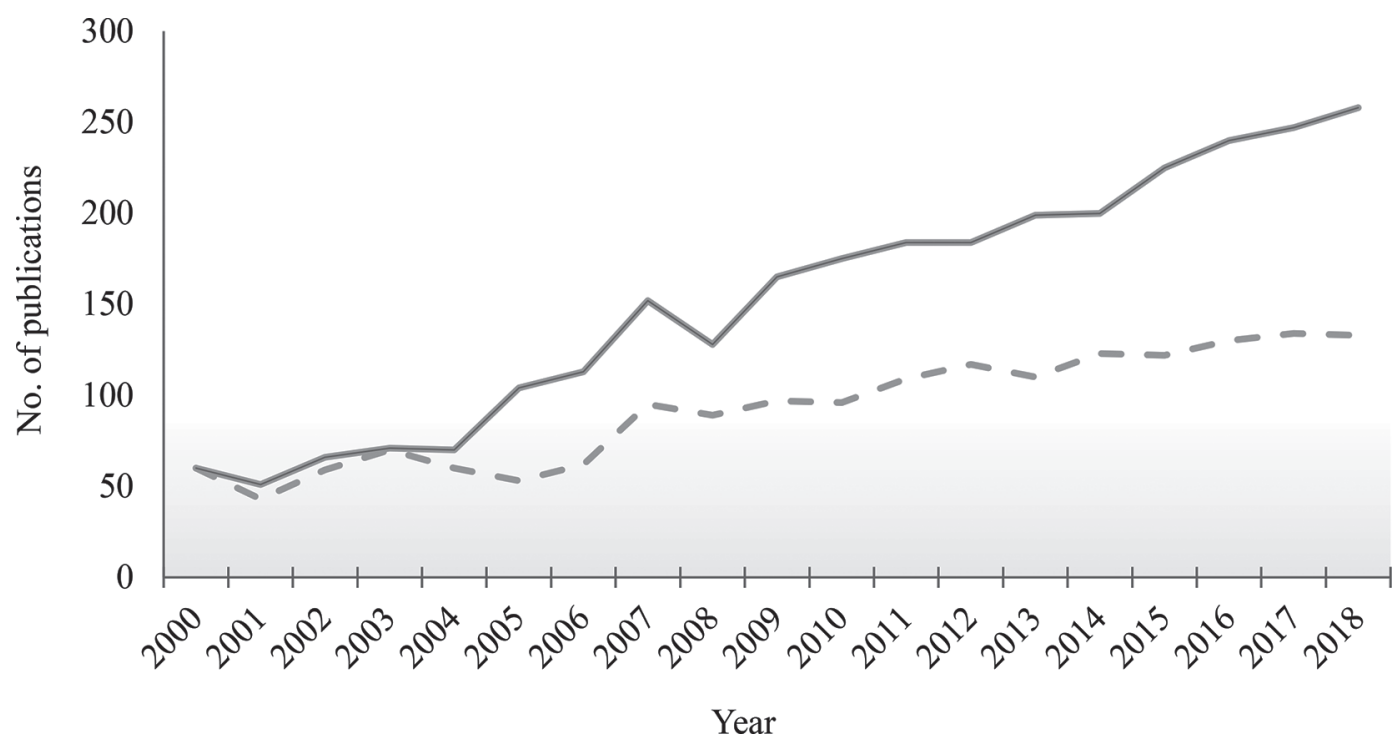

Figure 1. Number of published articles, reviews, and conference papers that cite the key words "lactose, dairy" (solid line) or "lactose, cow, milk" (dashed line) in the title or in the abstract. Source: Scopus, www.scopus.com.

understand if and how this trait can be exploited in the dairy field.

\section{SYNTHESIS AND CHEMICAL FORMS OF MILK LACTOSE}

\section{Biosynthesis Pathways}

Lactose is synthesized in the udder from blood glucose absorbed by the basal membrane of mammary epithelial cells (Osorio et al., 2016). Around 20\% of the circulating blood glucose of a dairy cow is converted into lactose during lactation (Cant et al., 2002; Rigout et al., 2002). Together with some minerals (Na, K, and $\mathrm{Cl}$ ), lactose contributes to the equilibrium of the bloodmilk barrier, being the main osmotic regulator between the blood and alveolar lumen. In fact, lactose determines the amount of absorbed water in the alveoli, and thus, the volume of produced milk (Fox et al., 2015). As soon as lactose is synthesized by the Golgi, it is packed into secretory vesicles. Here, LP determines a strong osmotic pressure, because this disaccharide cannot pass through the vesicle membrane; water is required to get into the secretory vesicles and re-establish equilibrium.

The uptake of the precursor (glucose) from the circulatory system is regulated by facilitative glucose transporters, whose genetic expression also directly affects milk synthesis (Zhao, 2014). After translocation, operated both by glucose transporters 1 and 8 , and by $\mathrm{Na}^{+}-$ dependent transport, glucose is partly absorbed into the Golgi of the epithelial cells and partly epimerized to uridine diphosphate (UDP)-glucose and then to UDPgalactose by the enzymatic actions of UDP-glucose-pyrophosphotylase-2 and phosphoglucomutase-1 (Figure 2 ). The same transporters carry UDP-galactose into the Golgi, where the lactose synthase, a heterodimer enzyme composed by $\alpha$-LA and $\beta$-1,4-galactosyltransferase, catalyzes this chemical compound, releasing the UDP fragment. In particular, $\beta$-1,4-galactosyltransferase connects the carbon atom 1 of galactose and the carbon atom 4 of glucose. The role of $\alpha$-LA is to increase the specificity of $\beta-1,4$-galactosyltransferase for glucose, so its concentration is usually highly correlated with the amount of lactose in milk (Fox et al., 2015). After formation, lactose-containing vesicles are released into the alveolar lumen from the apical membrane of the cell through facilitated transport (Zhao, 2014).

\section{Lactose Forms}

The glycosylic bond $(1,4)$ connects the carbon atom 1 of galactose and the carbon atom 4 of glucose and, as for other carbohydrates, lactose might assume 2 anomeric forms: o- $\beta$-D-galactopyranosyl-(1,4)- $\alpha$-D-glucopyranose, known as $\alpha$-lactose, and o- $\beta$-D-galactopyranosyl- $(1,4)$ $\beta$-D-glucopyranose, known as $\beta$-lactose. At $20^{\circ} \mathrm{C}$, total lactose is composed of $37.3 \% \quad \alpha$-lactose and $62.7 \%$ $\beta$-lactose; the dynamic equilibrium between the 2 forms is influenced by factors such as total LP, temperature, $\mathrm{pH}$, and the presence of co-solutes. The $\alpha$-lactose increases its stability when associating with 1 molecule of water, defined as water of crystallization; for this 
reason, it is usually referred as lactose monohydrate, and its molar weight is $360.31 \mathrm{~g} / \mathrm{mol}$ (Fox et al., 2015). A transition between the 2 configurations occurs when a glucose monomer converts to an open aldeide form, with acid, base, or water acting as a catalyzing agent. As a result, anomeric acetal carbon of glucose can change its configuration from $\alpha$ to $\beta$, or vice versa. The 2 lactose isoforms differ in solubility, specific rotation, and sweetness. Such differences are crucial for technological treatments of lactose, such as spray-drying, crystallization, and downstream applications. Both $\alpha-$ and $\beta$-lactose exhibit the same nutritional profile (Fox et

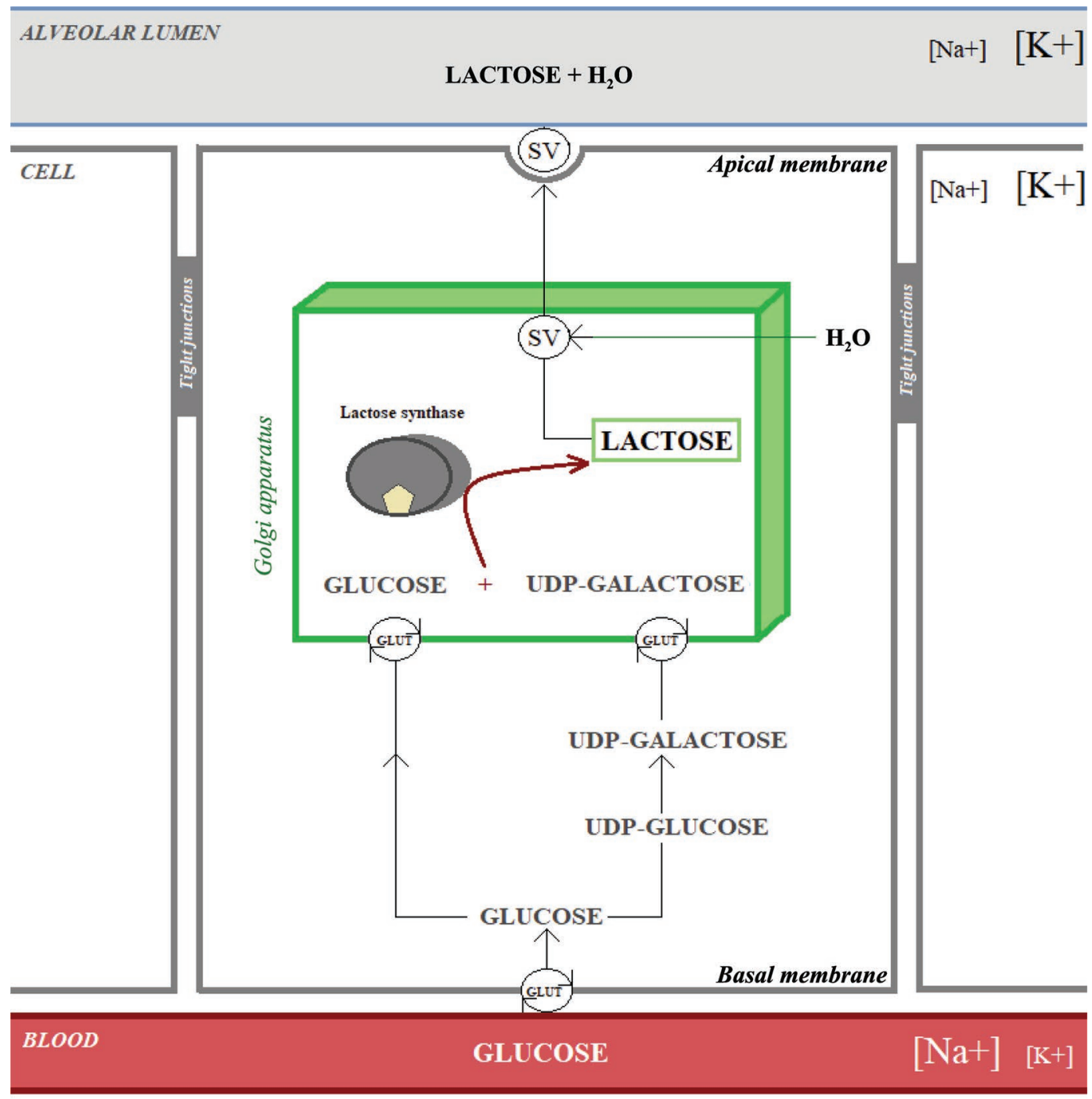

Legend:

$\begin{array}{ll}0 \text { galactosyltransferase } & \text { (SV) secretory vesicle } \\ \bigcirc \quad \text { LAT glucose transporter }\end{array}$

Figure 2. Schematic representation of the steps required for milk lactose synthesis in mammary epithelial cells. UDP $=$ uridine diphosphate. 
al., 2015), so for convenience, the ring tests coordinated by the International Committee for Animal Recording consider $\alpha$-lactose to be the reference for laboratory comparison. The aldehydic form of lactose is present in milk in very low amounts and with a highly dynamic equilibrium; it tends to be immediately converted to the cyclic form. Nevertheless, the aldehyde group acts as a reducing agent and can interact with proteins through Maillard reactions.

\section{HUMAN INTOLERANCE}

Lactase enzyme, called $\beta$-galactosidase, hydrolyzes lactose into glucose and galactose in the digestive tract of mammal newborns. This enzyme is synthesized in the small intestine by microvilli, and in humans it is encoded by the lactase gene on chromosome 2 from 135.787 to $135.837 \mathrm{Mb}$ (Domínguez-Jiménez and Fernández-Suárez, 2017; NCBI, 2018). Depending on population structure and genetic predisposition, the synthesis of this enzyme may decrease progressively with age, leading to difficulties in digesting milk and food containing lactose (Leonardi et al., 2012). This disorder, typically referred to as "lactose intolerance," is characterized by diarrhea and abdominal pain occurring immediately after the ingestion of lactose. In fact, as soon as lactose enters the intestinal environment, its concentration increases because of the absence of the lactase enzyme. This induces water to move from the blood into the intestinal tract to re-establish osmotic equilibrium, and it activates anomalous fermentations, with subsequent abdominal bloating and stomach pain.

Some differences exist between populations in toleration of lactose; for example, people from Nordic European countries and some African populations have a genetic predisposition for synthesizing lactase even in late age (Fox et al., 2015). Approximately $70 \%$ of the world population is at high risk of manifesting lactose intolerance, and prevalence has increased in the last decade, explaining why lactose-free products have gained importance in the marketplace (Domínguez-Jiménez and Fernández-Suárez, 2017). The most popular technological treatment for obtaining lactose-free milk is ultrafiltration (McCain et al., 2018), although it leads to an undesired removal of minerals from milk. To avoid the loss of important milk components, other methods have been developed to depress lactose through hydrolysis (McCain et al., 2018). For example, the addition of enzymes, specific molds, or yeasts (e.g., Aspergillus and Kluyveromyces spp.) during cheesemaking, milk heat treatment, or both allows for the separation of galactose and glucose, which are more digestible (Fox et al., 2015). The natural production of lactose-free milk in bovine species is biologically impossible, because lactose is the main milk osmole.

\section{MILK LACTOSE: APPLICATIONS AND MARKET DEMAND}

\section{Industrial Uses}

After cheesemaking, more than $90 \%$ of the lactose ends up in whey (Prazeres et al., 2012). Whey composition differs from that of milk, with average water, fat, and protein content of $93.9,0.20$, and $0.60 \%$, respectively. Along with lactose, non-casein-related proteins and water-soluble vitamins are also found in the whey (Prazeres et al., 2012; Sturaro et al., 2014). The processing of $100 \mathrm{~kg}$ of whole milk into cheese leads on average to $85 \mathrm{~kg}$ of whey, which yields $5.36 \mathrm{~kg}$ of whey powder (CLAL, 2018). Therefore, the major international cheese manufacturers - the Netherlands, Germany, France, and Italy (CLAL, 2018)-produce significant amounts of whey, which was previously discarded as a byproduct of cheese factories and either dumped or fed to animals. Although alternative uses for whey are scarce, whey is still common in the liquid feeding system of Italian heavy pigs (up to $25 \%$ of ration; Martelli et al., 2002). With the purpose of improving the efficiency of the dairy industry, several studies have shown that whey is a source of exploitable high-nutrition and high-value compounds (Sturaro et al., 2014). Among the available methodologies, filtration is the most commonly adopted technology in the dairy industry for extracting lactose, because of its quality-to-cost ratio. Membrane separation was introduced in the first years of the 21st century, and it allows solid recovery and (purified) water-saving. Whey filtration is performed using different membranes at different retention efficiencies: ultrafiltration ( $<40 \%$ of lactose retention) and nanofiltration ( $>90 \%$ of lactose retention). The purity of crystalized solid lactose could be improved through reverse osmosis, concentration, and spray-drying (Prazeres et al., 2012). Depending on whether the recrystallization process is used in the last step, lactose powder is sold in either pharmaceutical and edible forms, coded as HS170211 and HS170219, respectively, in the Harmonized System nomenclature (CLAL, 2018). The pharmaceutical form is used as excipient for drug tablets, and edible lactose is commonly used as a base for confectionery and infant formula. The sweetness of lactose is less intense than that of common sugars (around 20\% lower), making it an important ingredient for baked goods, ice creams, chocolate, and candies.

Whey permeate including lactose can be used as feed substrate for Xanthomonas bacteria in xanthan 
gum plants (Fox et al., 2015; Niknezhad et al., 2015). Xanthan gum is mostly used by food factories for its physical properties and industrial applications (GarcíaOchoa et al., 2000; Murad et al., 2017). Pretreated hydrolyzed lactose is reported to be the most efficient and cheapest source of carbon for the production and excretion of this biopolymer by Xanthomonas campestris (Murad et al., 2017).

\section{Market Demand}

In January 2014, the price of lactose on the international market reached US $\$ 1,826 / t$, the highest historical value ever reached in the Global Dairy Trade auctions, but then declined to an average value of about US $\$ 800 / t$ (Global Dairy Trade, 2018). In September 2018, the price was US $\$ 917 /$ t (Global Dairy Trade, 2018), driven by high demand for powders from Asia, but this demand slowed with the Chinese market financial crisis.

The international standard for milk-powder production set an LP standard in the starting matrix, so in some countries, such as New Zealand, solid lactose has been imported for a long time from supplier countries (Lithuania, the Netherlands, Denmark, the United States, Germany, and Australia; CLAL, 2018) to reach the right starting milk composition (Sneddon et al., 2015) and to maximize milk-powder yield. Nowadays, for the same purpose, New Zealand uses lactose derived from the whey left after cheesemaking. Indeed, production and import/export of lactose is a business that involves several countries (Geary et al., 2010; CLAL, 2018). For instance, in Italy the export volumes and the market value of edible lactose increased from 2014 to 2017. In recent years, the market value for edible lactose has moved from $€ 2.00$ to $€ 5.50 / \mathrm{kg}$ for global exports and from $€ 1.20$ to $€ 6.08 / \mathrm{kg}$ for European Union exports (CLAL, 2018). In the global market, the export of lactose powders has shown a linear positive trend over the years, with the major exporters being Germany and the Netherlands. The exports of pharmaceutical and edible lactose in 2012 were 142,617 and 9,352 t, respectively, and in 2017 they increased to 189,994 and 12,429 t, respectively. Global demand for pharmaceutical lactose was evidently greater than that for edible lactose (CLAL, 2018), but trends in 2017 were both positive and increased by $9.6 \%$ (pharmaceutical) and $14.6 \%$ (edible) compared with 2016 . It is also important to consider United States stocks of lactose, which could drive the global availability and market price of this product. According to Italy and to its whey surplus, both pharmaceutical and edible lactose powders are sold in the international market, with ex- ports in 2017 of 29,777 and 112 t, respectively (CLAL, 2018 ); in particular, the Italian export of edible lactose in 2017 reached a very high peak $(+350 \%)$ compared with previous years; the major international importers were Slovenia (39.0\%), Australia (16.9\%), and Romania (10.6\%; CLAL, 2018). France imported one-third of the pharmaceutical lactose produced in Italy in 2017, and other importers included Spain, the Netherlands, Iran, and the Russian Federation (CLAL, 2018).

\section{QUANTIFICATION OF LACTOSE AND VARIATION IN BOVINE MILK}

According to ISO 22662:2007 (ISO, 2007), the reference method for lactose determination in raw, heattreated, and dried milk is HPLC. However, with ISO 26462:2010 (ISO, 2010), the enzymatic method using difference in $\mathrm{pH}$ has been accepted for lactose quantification in milk samples. In the last 2 decades, introduction of the infrared spectroscopy technique in the routine analysis of milk has led to a revolution in dairy monitoring systems, allowing for monthly determination of LP in milk at the individual cow level (De Marchi et al., 2014). The predictions of LP from spectra are accepted for both scientific and economic purposes; indeed, a correlation of 0.996 in validation studies has been declared between measured and predicted LP (application note 5373 Rev. 3, MilkoScan 7RM/FT+/6000; Foss, Hillerød, Denmark). Some novel automatic and conventional milking systems are equipped with optic in-line measurement of milk composition, including LP and physical parameters (Lely Holdings, the Netherlands; Fullwood Ltd., United Kingdom). These technologies are becoming important tools, because their software can collect and store data and elaborate on information, reporting alerts for cows with potential problems, so that farmers can provide special treatment. In the case of LP, dramatic changes or specific patterns could be informative with respect to the cow's mammary gland health and energy balance; however, no studies have investigated LP changes and patterns in dairy cattle so far.

Milk LP shows variability, which depends on several factors (Fox et al., 2015). Studies discussing the effect of parity on LP are summarized in Table 1. Milk from first-calving cows has higher LP than milk from cows in later lactations; Haile-Mariam and Pryce (2017) and Costa et al. (2018) reported a gradual decrease in LP across parities in Australian dairy cattle and Italian Holsteins, respectively. Even if differences in LP are present among all parity orders, the major gap is between primiparous and multiparous animals (Løvendahl and Weibjerg, 2017; Costa et al., 2018). It is important 
to consider that mastitis is usually more common in herds with a high percentage of multiparous cows, because primiparous cows tend to be less susceptible to udder inflammation; also, the milk of multiparous cows has generally higher SCC than the milk of primiparous cows (Harmon, 1994; Koeck et al., 2010). Because LP tends to decrease when clinical or subclinical udder inflammation is present and SCC increases, the LP gap between parities could be explained by the difference in milk SCC across cows of different lactations. A schematic representation of mechanisms relating LP, LY, and mastitis is depicted in Figure 3. In addition, a physiological (but not yet studied) mechanism could be that multiparous cows produce more milk, but with lower LP. This could suggest that both the osmotic function of lactose and the osmotic equilibrium between blood and milk could change in different parities. Finally, the cumulative effect of mastitis cases, repeated lactations, stage of lactation, and aging could affect mammary epithelium integrity and permeability, translating into gradual LP reduction during the productive life of a cow (Zhao, 2014; Herve et al., 2018). Lactose percentage does not show the usual lactation curve shape of fat and protein percentages; indeed, the lactation curve of LP is strictly related to that of milk yield, as already described in the section on the physiological mechanisms and pathways of lactose synthesis at the mammary level. Lactose is not affected by milk dilution through DIM, and it reaches the lowest values in late lactation, similar to milk yield and in an opposite trend to fat and protein percentages (Ptak et al., 2012; Penasa et al., 2016; Haile-Mariam and Pryce, 2017).

Effects of the dietary energy level on LP have also been investigated. Xue et al. (2011) reported significantly greater LP in the milk of cows fed a high dietary concentrate, and Ouweltjes et al. (2007) reported similar outcomes in a Dutch study; in particular, cows fed a high-energy diet had higher milk LP than cows fed a low-energy ration. Beerda et al. (2007) reported that LP significantly decreased by $15 \%$ in the milk of cows fed a low-caloric-density diet. Internationally, diet manipulation to increase LP is not economically justified or possible in the current era. Indeed, even major dairy powder producers and exporters such as New Zealand do not have feeding recommendations to increase milk LP (Sneddon et al., 2015).

\section{MILK LACTOSE AND HEALTH TRAITS}

\section{Lactose as Biomarker of Metabolic Disorders}

Glycemia and energy balance in cows are positively correlated with LP (Reist et al., 2002; Larsen and Moyes, 2015), especially in high-producing breeds (Lemosquet et al., 2009). Lemosquet et al. (2009) suggested that post-hepatic blood glucose availability could be an indirect key regulator of milk yield, making blood glucose directly responsible for LY. Hence, it is important to highlight the dependence of milk yield on LY and that the uptake of glucose from the blood to produce lactose is a metabolic priority in specialized dairy animals. In fact, udder requirements are subjected to homeorhesis in high-producing cows; that is, milk composition is unaltered even in case of breakdown of body reserves (Bauman and Currie, 1980; Zhao, 2014). For example, a sudden decrease of dietary energy level or increase in energy demand in high-yield cows could result in a negative energy balance and mobilization of fat reserves from tissue to blood, passing through the liver. Supporting this view, a negative phenotypic association $(-0.17)$ between LP and milk BHB, one of the most common indicators of ketosis in dairy cows, has been reported by Larsen and Moyes (2015). Indeed, BHB levels can be measured in individual milk through keto tests or infrared milk analysis, and may help farmers identify cows in negative energy balance and ketosis. In fact, because LP is strictly dependent on blood circulating glucose, milk from (sub)ketotic cows tends to show lower LP and higher BHB than healthy animals, especially in early lactation. Evaluating the association between blood parameters and milk composition traits, Cant et al. (2002) reported a significant difference in LP between cows infused with 2 different solutions (glucose vs. saline), indirectly confirming the relation between LP and (sub)clinical ketosis. An average phenotypic correlation of -0.17 was found between LP and blood BHB in Norwegian Red cows (Belay et al., 2017). In addition, in a study in Fleckvieh cows,

Table 1. Summary of the literature dealing with a decrease of milk lactose percentage by increasing parity and SCC/SCS

\begin{tabular}{ll}
\hline Item & Reference \\
\hline Parity & Miglior et al. (2006), Ptak et al. (2012), Malchiodi et al. (2014), Fox et al. (2015), Alessio et al. (2016), Haile-Mariam and \\
SCC/SCS & $\begin{array}{l}\text { Pryce (2017), Costa et al. (2018) } \\
\text { Pyörälä (2003), Bansal et al. (2005), Forsbäck et al. (2010), Gillon et al. (2010), Malek dos Reis et al. (2013), Moyes et al. } \\
\\
\text { (2014), Cinar et al. (2015), Fox et al. (2015), Kester et al. (2015), Nasr and El-Tarabany (2017), Costa et al. (2018) }\end{array}$ \\
\hline
\end{tabular}




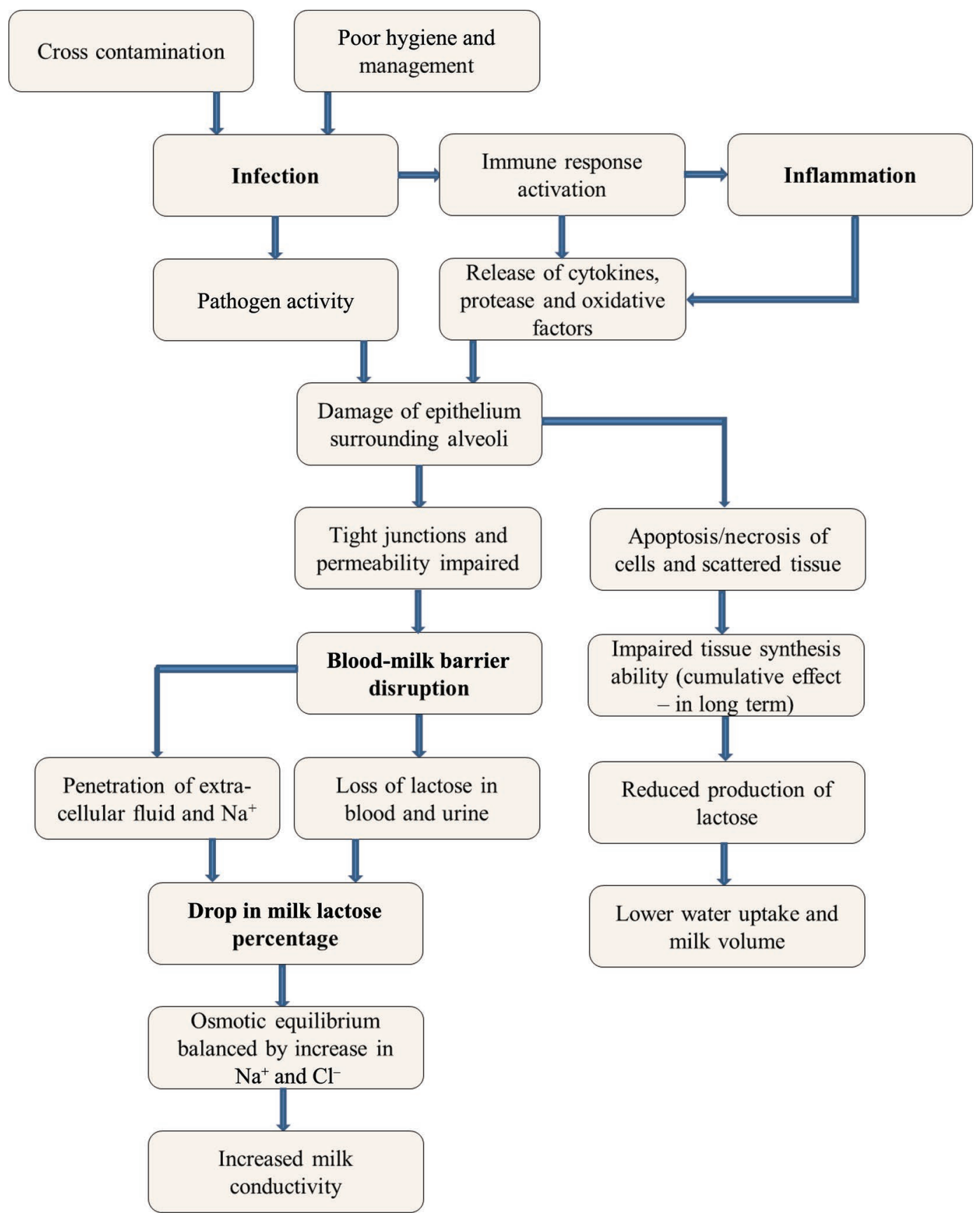

Figure 3. Diagram of the cause-effect relationships between lactose and mastitis in cows.

Ederer et al. (2014) found that ketosis was correlated with depressed LP $(-0.15)$, increased fat percentage (0.21), and increased fat-to-lactose ratio (0.15) in early lactation, confirming that ketosis alters both fat percentage and LP in milk, even if with opposite effects. These results suggest that the relationship between milk lactose and gluconeogenesis in dairy cows should be further investigated, to detect and propose novel health indicators in milk.

\section{Lactose and Mastitis}

Mastitis is a disease that can occur throughout an entire lactation, with peaks in the first few months after calving. Studies of the effects of high SCC on milk LP are summarized in Table 1. Phenotypic correlations between LP and SCS range from -0.15 (Hossein-Zadeh and Ardalan, 2011) to -0.66 (Vilas Boas et al., 2017); in this sense, LP has been widely reported to be one of 
the most informative traits for mastitis diagnosis, other than SCC and milk electrical conductivity (Geary et al., 2014; Fox et al., 2015; Vilas Boas et al., 2017). The reduction of LP in milk during mastitis (Figure 3 ) has 3 main causes: (1) LP synthesis is partly compromised because secretory cells are damaged by inflammation and infection; (2) a great, but still undefined, part of the lactose is lost in urine, because of a disruption of tight junctions and altered permeability of the basal membrane of the mammary cells that separates blood and milk; (3) mastitis pathogens use available milk lactose as a substrate, reducing LP and increasing lactic acid in milk. During mammary tissue inflammation, the osmotic balance is maintained by an increase of $\mathrm{Na}^{+}$and $\mathrm{Cl}^{-}$; in particular, $\mathrm{Na}^{+}$derived from the highly $\mathrm{Na}^{+}$-concentrated extracellular environment is the main ion responsible for the increase of the electrical conductivity and salty taste of milk (Figure 3). In addition, a formula to estimate the Koestler number $(\mathbf{K n})$ is reported in the literature, which relates milk $\mathrm{Cl}^{-}(\%)$ and LP (Fox et al., 2015): $\mathrm{Kn}=\left[\left(\right.\right.$ milk Cl$\left.{ }^{-}\right) \times$ 100]/(milk LP). The Kn could be used to discriminate normal $(\mathrm{Kn}<2.00)$ and abnormal $(\mathrm{Kn}>3.00)$ milk. Finally, for the same reason, the electrical conductivity of milk is negatively related to LP (Fox et al., 2015; Vilas Boas et al., 2017; Ebrahimie et al., 2018). This background suggests that the complementary information from LP, SCC, and electrical conductivity can be used to provide an accurate diagnosis of mastitis at the individual level, and some authors have recently highlighted the potential of alternative or derived traits (or both) as predictors of udder inflammation. For instance, in the machine learning-based study of Ebrahimie et al. (2018), LP and electrical conductivity were the most reliable indicators of subclinical mastitis (together with SCC) and were able to recognize predictive patterns of subclinical mastitis in Holstein cows reared in New Zealand. Standard acceptable definitions of biological markers have been given by the Biomarker Definitions Working Group in Clinical Pharmacology and Therapeutics (Atkinson et al., 2001): "a characteristic that is objectively measured and evaluated as an indicator of normal biological processes, pathogenic processes, or pharmacologic responses to a therapeutic intervention." Therefore, considering the existing relations between LP and the traits above, lactose and perhaps its ratios with fat, protein, or both could be considered as potential biomarkers for early-lactation metabolic diseases, as reported by Ederer et al. (2014) in Fleckvieh cows. Nevertheless, further research is needed to validate LP as a reliable indicator. The adoption of precision farming technologies on a large scale will allow for the daily monitoring of individual milk and patterns of certain milk components that could be used to detect health disorders (de Haas, 2003) and prompt treatment.

\section{GENETICS OF MILK LACTOSE}

\section{Dairy Species and Cattle Breeds}

Considering the most common dairy species, average milk LP of 4.10, 4.70, and $4.90 \%$ have been reported in the literature for goats, cows, and sheep, respectively (Fox et al., 2015). Milk from buffalo shows LP similar to cow milk (4.50 to $5.20 \%$ ), but with more variation across countries and breeding systems (El-Salam and El-Shibiny, 2011). Some studies (Malchiodi et al., 2014; Gottardo et al., 2017) have investigated the effect of cattle breed on milk composition, but there is no consensus on the effect of breed on LP.

\section{Heritability and Repeatability}

A summary of LP heritabilities for the first 3 lactations in dairy cows is presented in Figure 4. Lactose percentage usually shows higher heritability than milk yield and other milk solids (Gillon et al., 2010; Sneddon et al., 2015; Haile-Mariam and Pryce, 2017), with a moderate to high contribution of additive genetic variance to phenotypic variance. A heritability of nearly 0.40 is generally considered for LP in Holstein-Friesian cattle; however, there is no consensus on trends of heritability across parities. In fact, heritabilities of $0.478,0.506$, and 0.508 have been reported for Canadian Holsteins in parities 1, 2, and 3, respectively; on the other hand, Rzewuska and Strabel (2013) have reported heritabilities that were higher in first- $(0.34)$ than in second- (0.28) and third-parity (0.26) Polish Holstein cows. Other studies (Haile-Mariam and Pryce, 2017; Satoła et al., 2017) did not detect differences in LP heritability across parity number (Figure 4). According to Haile-Mariam and Pryce (2017), LP heritability increased in the first 150 DIM and remained almost stable thereafter. Moreover, Belay et al. (2017) reported heritability of LP in the first half of lactation that was 0.406 from 11 to 30 DIM and 0.458 from 61 to 90 DIM. Genetic studies dealing with estimates of testday records reported medium to high repeatability for LP (Table 2), suggesting that few observations within lactation are enough to capture the overall variability in LP. Estimates of heritability for LY range from 0.10 to 0.20 . Due to the very high correlation of LY with milk yield, genetic parameters have been reported in a few countries so far, including New Zealand (Sneddon et al., 2015), Australia (Haile-Mariam and Pryce, 2017), and Italy (Tiezzi et al., 2013; Costa et al., 2018). 
Table 2. Published estimates of heritability and repeatability (SE) of lactose percentage

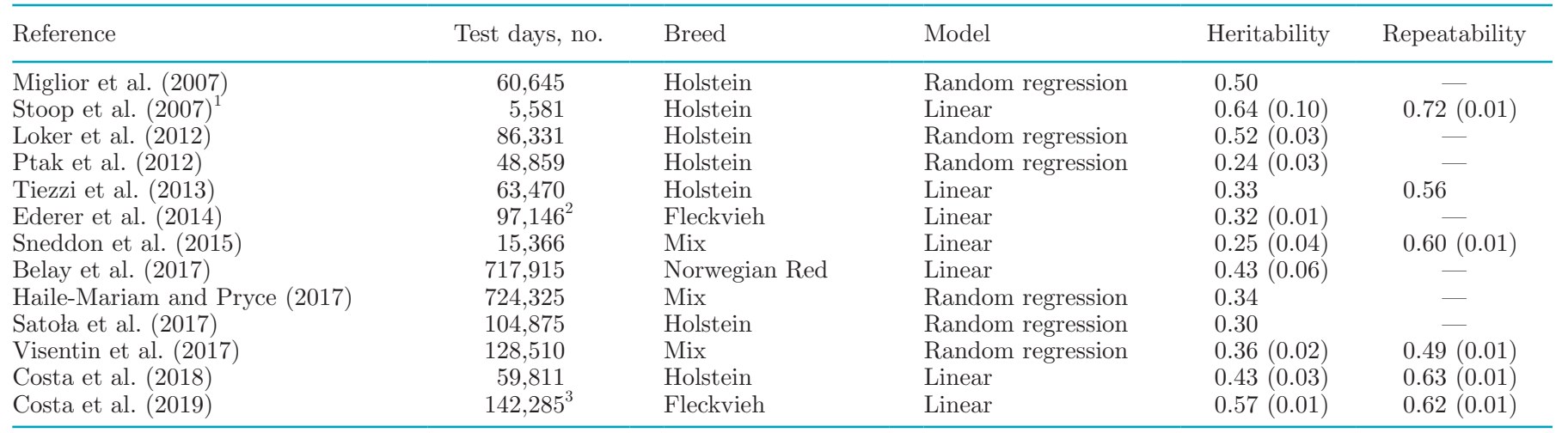

${ }^{1}$ First-calving cows.

${ }^{2}$ Lactation records.

${ }^{3}$ Lactation records from the first 150 DIM.

\section{Genetic Correlations with Traditional Milk Traits}

Lactose percentage is not included in any breeding program for dairy cattle around the world, but it is routinely available as a part of normal herd testing and has been widely included in several genetic studies. However, it has been treated as an "accessory" and seldom discussed, likely due to its low and variable economic merit. Some genetic correlations involving LP exist in the literature, but further studies are required to improve our understanding of the genetic aspects of this trait and its relationship with other milk components. Milk yield and LP have been reported to be weakly genetically correlated (Miglior et al., 2007; Samoré et al., 2010; Sneddon et al., 2015; Visentin et al., 2017); in fact, LP is osmotically determined by the amount of water absorbed from the cell cytosol and the blood. Therefore, at least theoretically, LP is independent of

Satola et al. (2017)

Haile-Mariam and Pryce (2017)*

Rzewuska and Strabel (2013)

Hossein-Zadeh and Ardalan (2011)
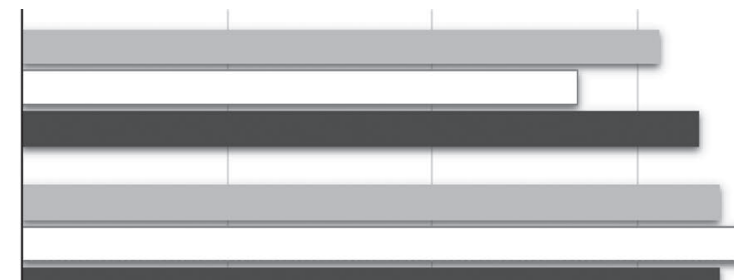

Miglior et al. (2007)

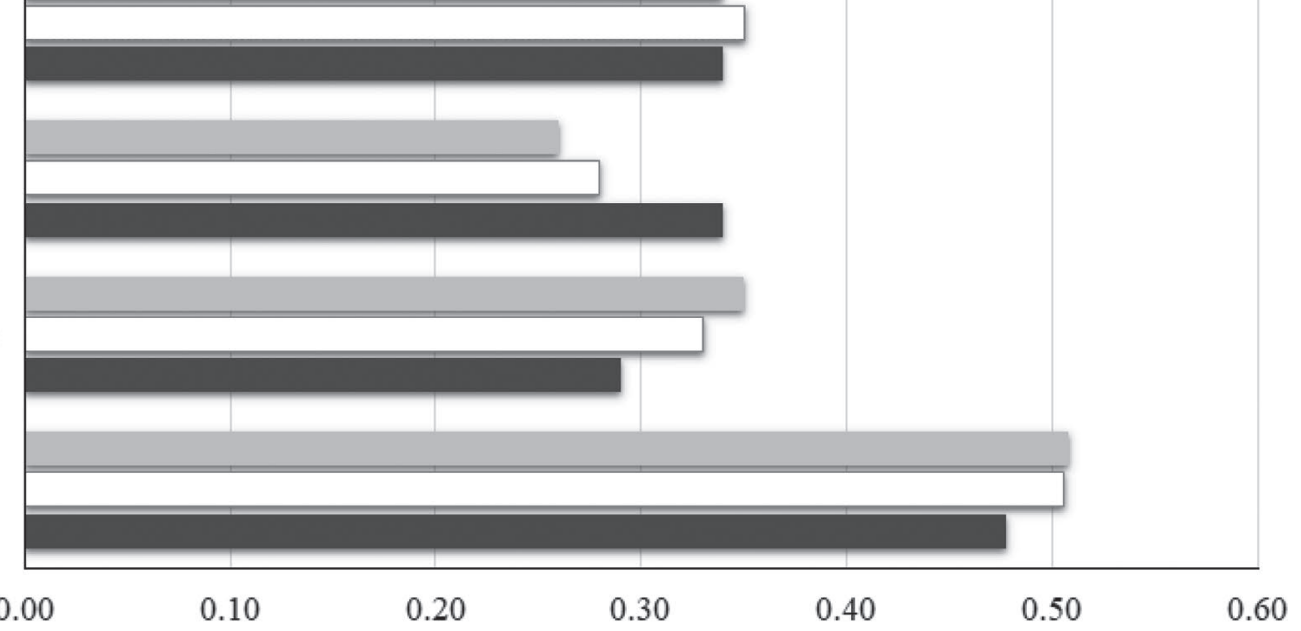

Heritability

Figure 4. Estimates of heritability for lactose percentage in the milk of Holstein cows of different parities (parity $1=$ black bars; parity $2=$ white bars; parity 3 = gray bars). *Cows in Haile-Mariam and Pryce (2017) study were $75 \%$ Holstein, $15 \%$ Holstein $\times$ Jersey, and $10 \%$ Jersey. 
LY, but the physiological pathways are not fully understood. Lactose yield, on the other hand, is strongly genetically associated with milk yield, with estimates close to 1 (Sneddon et al., 2012, 2015; Haile-Mariam and Pryce, 2017), and thus genetic correlations of LY or milk yield with other traits are similar (Sneddon et al., 2012, 2015). Genetic correlations of LP with fat and protein percentages are weak or close to zero (Miglior et al., 2007; Stoop et al., 2007; Visentin et al., 2017). However, using random regression models, some authors have reported variations in covariance estimates both within and across lactations (Haile-Mariam and Pryce, 2017; Satoła et al., 2017). For instance, Satoła et al. (2017) reported a trend for genetic correlations of LP with fat and protein percentages across DIM of first-parity cows that resembled the shape of the lactation curve for milk yield, with a peak in early lactation. Haile-Mariam and Pryce (2017) observed a shift from moderately positive $(0.30)$ to moderately negative $(-0.24)$ genetic correlation between LP and protein percentage moving from early to late lactation. Satoła et al. (2017) reported stronger genetic associations of LP with fat and protein percentages in first parities compared to later parities, whereas Haile-Mariam and Pryce (2017) found stronger correlations between LP and fat and protein percentage in third-parity cows compared to first-parity cows. Genetic relationships between casein (which plays a fundamental role in the cheesemaking process) and LP and LY have not been reported or discussed in the scientific literature so far. A moderate negative genetic correlation $(-0.46)$ between LP and milk freezing point has been reported by Costa et al. (2018), and this result was somewhat expected, because milk freezing point, which is an indicator of milk dilution, is affected by the concentration of milk solids, the most abundant being lactose.

\section{Genetic Correlations with Health Traits}

Lactose has been already suggested as a potential health indicator in cows (Reist et al., 2002; Pyörälä, 2003; Bansal et al., 2005; Forsbäck et al., 2010; Gillon et al., 2010; Ederer et al., 2014; Haile-Mariam and Pryce, 2017). A collection of published genetic and phenotypic correlations between LP and SCS is presented in Table 3. Genetic correlations of -0.24 and -0.10 have been reported between LP and clinical mastitis in early lactation or across the whole lactation, respectively (Bastin et al., 2016), and Costa et al. (2019) reported a genetic correlation of -0.18 between LP and mastitis in the first 150 DIM of Fleckvieh cows. Traditional traits used for mastitis identification, such as SCS, are not always reliable across breeds or parity orders (Gillon et al., 2010). In fact, the correlation between mastitis and SCS is not always strong, with estimates from 0.30 to 0.70 (Mrode et al., 1998). All of these considerations stress SCS may not be sufficient to diagnose mastitis, because different pathogens affect milk SCS in different ways and magnitudes (dos Reis et al., 2013; Bobbo et al., 2017). Besides the association with mastitis and SCS, milk LP is also strictly related to cow energy balance and available blood glucose (see Biosynthesis Pathways, above). Moreover, the fat-tolactose ratio in early lactation has been reported to be an indicator of cow energy balance, heritable (0.19), and genetically associated with clinical ketosis $(-0.25$; Ederer et al., 2014; Bastin et al., 2016). In addition, LP seems to be negatively related to BHB (blood and milk concentrations) and milk fat-to-protein ratio (Loker et al., 2012; Belay et al., 2017), usually referred to as markers of ketosis and negative energy balance. In fact, Belay et al. (2017) estimated negative genetic correlations between LP and blood BHB, with values of $-0.234,-0.172,-0.159$, and -0.154 from 11 to 30 , 31 to 60,61 to 90 , and 91 to 120 DIM, respectively. In the same study, using a restricted data set, genetic correlations of LP and LY with ketosis were -0.043 and 0.161 , respectively. Moreover, both LP and LY were genetically associated with ketosis in Fleckvieh breed, with estimates of -0.16 and 0.42 , respectively (Costa et al., 2019). A positive association of LP with fertility in the subsequent lactation has been reported by Bastin et al. (2016), highlighting better fertility in cows yielding milk with higher LP. Both milk LP and fertility depend on cow energy balance (Bastin et al., 2016), meaning that their relationship is likely indirect. On the other hand, Costa et al. (2019) found that genetic correlations were close to zero between LP and some fertility disorders, namely retained placenta and ovarian cysts. In the last decade, several authors have coupled LP and milk urea as an indicator of metabolic health (Miglior et al., 2006, 2007; Loker et al., 2012; Satoła et al., 2017). These 2 traits are negatively associated, with an average genetic correlation of -0.15 , and Miglior et al. (2007) reported that the genetic correlation was stronger in later-parity cows than in first-parity cows. Furthermore, Loker et al. (2012) reported a positive genetic correlation between LP and body condition score at 5 (0.27), 50 (0.31), and 150 (0.25) DIM, again suggesting that generally healthier cows produce milk with greater LP.

Finally, it should always be considered that LP has a moderate to high heritability, even across breeds and parities, whereas health traits do not (Egger-Danner et al., 2015; Pryce et al., 2016; Martin et al., 2018). On the other hand, LP has limited variability, which makes its use for genetic purposes difficult (Costa et al., 2018). Despite this, the availability of daily infor- 
Table 3. Estimates of phenotypic and genetic correlations (SE) between lactose percentage and SCC reported in the literature

\begin{tabular}{lrrlrl}
\hline Reference & $\begin{array}{c}\text { Test } \\
\text { days, no. }\end{array}$ & $\begin{array}{c}\text { Cows, } \\
\text { no. }\end{array}$ & Breed & $\begin{array}{c}\text { Phenotypic } \\
\text { correlation }\end{array}$ & $\begin{array}{c}\text { Genetic } \\
\text { correlation }\end{array}$ \\
\hline Stoop et al. (2007) & 5,581 & 1,953 & Holstein & $-0.24(0.02)$ & $-0.44(0.21)$ \\
Miglior et al. (2007) & 60,645 & 5,022 & Holstein & -0.23 & -0.20 \\
Gillon et al. (2010) & 590,083 & 113,905 & Mix & -0.38 & -0.35 \\
Hossein-Zadeh and Ardalan (2011) & 458,408 & 57,301 & Holstein & -0.15 & -0.19 \\
Sneddon et al. (2015) & 15,366 & 4,378 & Mix & $-0.19(0.01)$ & $-0.07(0.14)$ \\
Vilas Boas et al. (2017) & 680 & 268 & Gyr & -0.66 & -0.28 \\
Visentin et al. (2017) & 128,510 & 9,824 & Mix & $-0.25(0.01)$ & $-0.22(0.08)$ \\
Costa et al. (2018) & 59,811 & 4,355 & Holstein & -0.00 \\
\hline
\end{tabular}

mation on LP in future could be useful for detecting health disorders and for validation studies. In fact, except for some recent efforts in Austrian Fleckvieh cows (Costa et al., 2019), no other studies have attempted to properly validate LP or its ratio to other milk solids as an indicator of disease.

\section{Literature on Lactose EBV}

Correlations between EBV of LP (and LY) with EBV of traits under selection are very scarce. Miglior et al. (2007) and Haile-Mariam and Pryce (2017) estimated negative associations between EBV of LP and EBV of SCS (-0.164) and SCC (-0.150), respectively. A weak association between EBV of LP and EBV of milk yield was reported in both studies, with values of 0.101 in Canadian Holsteins (Miglior et al., 2007) and 0.06 in Australian dairy cattle (Haile-Mariam and Pryce, 2017). Conversely, a strong correlation has been reported between EBV of LY and EBV of milk yield, confirming the strong genetic relationship between these traits (Sneddon et al., 2015; Haile-Mariam and Pryce, 2017). Miglior et al. (2007) found favorable associations between EBV of LP and EBV of Canadian Lifetime Profit Index (0.139), median suspensory (0.112), mammary system (0.100), udder depth (0.128), and lactation persistency (0.329), which was defined as the expected milk yield at 280 DIM as a percentage of milk yield on 60 DIM in lactation. Although weaker, the correlation between EBV of LP and EBV of udder depth assessed by Haile-Mariam and Pryce (2017) was also positive (0.05); the same study reported favorable correlations of LP EBV with EBV of longevity (0.07) and fertility (0.08), indicating that on average the daughters of top bulls for LP tend to live longer and show better fertility than the average population. Moreover, the lifetime trend of LP and LY (e.g., maturity rate and persistency) could also add information and be related to traits of economic interest. The potential main critical points for the inclusion of LP in health indexes are: (1) the lack of deep knowledge on this feature; (2) the unknown effect of lactose on milk technological traits; and
(3) the absence of genetic evaluation for milk lactose worldwide. Finally, the inclusion of LP in a selection index would require preliminary cost-benefit analysis according to specific dairy-market conditions.

\section{Genome-Wide Association Studies}

Genome-wide association studies for LP and LY are very scarce in the literature. To the best of our knowledge, only Wickramasinghe et al. (2011), Lopdell et al. (2017), and Wang and Bovenhuis (2018) have performed such studies for LP in dairy cattle in the United States, New Zealand, and the Netherlands, respectively. The main purpose of Wickramasinghe et al. (2011) was to evaluate candidate genes responsible for high-value oligosaccharides in milk; B4GALT1 on chromosome 9, related to the transport of glucose, was significant for lactose biosynthesis. In particular, the expression of this gene was higher in the first part of lactation, corresponding to peak milk yield. These results confirmed the key role of lactose in determining milk volume and suggested that these 2 traits shared the same genetic evolution. Indeed, dietary requirements and feed intake in newborns are higher in the initial phase of lactation, and then progressively decrease as weaning age approaches. Through genome-wide association studies of LP and LY, Lopdell et al. (2017) identified significant regions coding for LP and LY on the genome related to transport mechanisms and osmoregulation of milk components. According to Lopdell et al. (2017) and Wang and Bovenhuis (2018), several regions code for LP and are spread over chromosomes 2, 3, 12, 16, 20, and 28 . Conversely, significant variants for LY were found on chromosomes 6 and 14 only (Lopdell et al., 2017).

\section{LACTOSE IN MILK PAYMENT SYSTEMS}

Payment systems (PS) are constructed as a method of approximating the true value of milk on the basis of its components and are the main tool of communication with the farmer (Geary et al., 2010). Single-component PS are based on volume of milk, regardless of milk 
quality and composition; multiple-component PS take the form of linear equations that usually include yields of fat and protein with a penalty for milk volume, or yields of fat, protein, and lactose with a penalty for milk volume. Volume charges are calculated as the ratio of the sum of all volume-related costs (i.e., unrelated to the quantity of the final product) to the volume of milk processed. Economic values in multiple-component PS are obtained by distributing the industry revenue plus any volume charges according to the ratio(s) of the marginal revenues for each component. Marginal revenues for milk components can be generated using different approaches; for instance, Geary et al. (2010) used the marginal rate of technical substitution to generate component values. This approach is similar to that suggested by Ladd and Dunn (1979) for estimating the value of milk components to a dairy manufacturer. Lactose has been considered a low-value milk component in the past, but the situation has changed in recent years as lactose has gained economic interest at international level. The implications of including lactose in New Zealand milk PS have been discussed by Sneddon et al. (2013), who stressed the need for proper genetic investigations simulating the inclusion of lactose into the payment formula, to estimate reliable economic merit. Sneddon et al. (2013) highlighted that LP and LY are very rarely included in milk price equations worldwide, but some PS put positive emphasis on solids-nonfat, indirectly accounting for lactose, whereas other PS put negative weight on milk volume, and therefore indirectly also on LY. However, updated information is unavailable; the last report dealing with a summary of existing PS of the International Dairy Federation (IDF, 2006) dates back to 2006. Finally, due to industrial secrecy, the milk payment equations of dairy producers and milk collectors are often not published. The following section aims to describe the PS of some large companies that include or somehow account for lactose in their PS.

\section{New Zealand}

The milk PS in New Zealand is known as "A + B - C," adopted by a prominent dairy company, the Fonterra Co-operative Group. The formula accounts for fat (A) and protein (B) and places a penalty on milk volume (C). One exception to "A + B - C" in New Zealand is the PS used by Synlait Milk Ltd., which also considers LY when paying suppliers. The system is called " $\mathrm{F}+\mathrm{P}$ $+\mathrm{L}-\mathrm{V}$," where F, P, L, and V are fat, protein, lactose, and milk yields. In particular, the economic values used during the $2010-2011$ season were NZ $\$ 4.24 / \mathrm{kg}$ of fat, $\mathrm{NZ} \$ 10.34 / \mathrm{kg}$ of protein, $\mathrm{NZ} \$ 1.84 / \mathrm{kg}$ of lactose and $\mathrm{NZ} \$ 0.0324 / \mathrm{L}$ of milk volume (2010 average: $\mathrm{NZ} \$ 1=$
US\$0.72), derived from the model proposed by Garrick and Lopez-Villalobos (2000). Comparing these 2 PS from New Zealand, Holmes et al. (2007) demonstrated that the inclusion of LY reduced the values of fat and protein by 7 to $9 \%$, with a value of LY that ranged from - NZ $\$ 0.416$ to $\mathrm{NZ} \$ 2.000 / \mathrm{kg}$, depending on the product portfolio of the milk and breed examined.

\section{The Netherlands}

FrieslandCampina is the main company in the Netherlands; its member farmers receive a so-called guaranteed price that is based on the monthly trend in the published milk prices of some North European benchmark reference companies, regardless of the performance of FrieslandCampina. However, because the quality of delivered milk differs among farms, the final amount paid depends on the supplied kilograms of protein, fat, and lactose at a ratio of 10:5:1. Fewer deductions are contemplated for fixed costs and cooperative schemes and, when appropriate, some premiums. The premiums are related to full or partial outdoor grazing, the Foqus planet, and special milk flows (FrieslandCampina, 2018).

\section{Ireland}

The Irish dairy industry uses the "A + B - C" PS, similar to the Fonterra Co-operative Group of New Zealand. However, some processors have set a penalty when LP is below a certain threshold (e.g., Dairygold Co-operative Society Ltd., 2011). In particular, penalties of $€ 0.10$, €0.05, and $€ 0.025 / \mathrm{kg}$ of milk are applied when LP is below $4.000 \%$, between 4.001 and $4.100 \%$, and between 4.101 and $4.200 \%$, respectively. The reason behind this penalty is the role of LP as a farm-specific indicator of udder health and as a proxy for processing ability of milk (Glanbiaconnect, 2016).

\section{United States}

Some PS in the United States follow a hundredweight (cwt) of milk plus fat or protein component, fat plus solids-not-fat, fat only, total milk solids, or volume of milk. This PS is complicated by a classification system, in which each class has different economic values (Jesse and Cropp, 2004). In particular, class I includes milk used for beverage products (i.e., "white" whole, low-fat, and skim milk in all container sizes, chocolate, and other flavored milks, liquid buttermilk, and eggnog). Class II milk is used for soft manufactured products, such as ice cream and other frozen dairy desserts, cottage cheese, and creams such as sour cream, aerosol whipped cream, whipping cream, half and half cream, and coffee cream. 
Class III milk is used for cream cheese and hard cheese, and class IV milk is used for butter and some dry milk products (Jesse and Cropp, 2004). Because the final value of the milk to the farmer is a composite of these classes, as well as of federal dairy product price-support programs such as the milk income loss contract (Chang and Mishra, 2011), determination of the value of independent milk components is more complicated than for the New Zealand dairy industry. The class III milk price (milk used for cheese production) is the basis for the majority of milk payments to dairy producers and it indirectly accounts for lactose, because it is based on the value of solids, with different prices for milk protein, milk fat, and other solids (lactose and minerals). In November 2017, protein, fat, and other solids were valued at US $\$ 8.00,3.59$, and $0.88 / \mathrm{kg}$, respectively. Dairy producers were paid on the basis of the amount of these 3 components; moreover, the class III price could be considered as an index that represents the value of milk with $3.00 \%$ protein, $3.50 \%$ fat, and $5.70 \%$ other solids (Geuss, 2013).

\section{Canada}

Dairy farmers of Ontario are paid according to butterfat, protein, and other solids supplied with their raw milk; therefore, this system indirectly accounts for lactose. The values for fat, protein, and other solids (lactose + minerals) used in May 2018 were CA $\$ 10.63$, 6.39 , and 1.36 (2018 average: CA $\$ 1=\mathrm{US} \$ 0.7786$ ), respectively (Dairy Farmers of Ontario, 2018).

\section{CONCLUSIONS AND FUTURE CHALLENGES}

So far, any genetic selection scheme for production that includes udder health and metabolic diseases accounts for LY or LP in dairy cattle worldwide (Interbull, 2018). Considering that both phenotypic and genetic correlations of LY with milk yield are close to unity, an indirect selection for LY already exists in these indexes, putting both positive and negative emphasis on milk yield. On the other hand, LP is moderately to highly heritable and genetically correlated with 2 important health traits, namely mastitis and ketosis. Nowadays, there is concern that selection based only on SCC/SCS will lead to a progressive loss of immune ability and immunological response to infections in subsequent generations (Rainard et al., 2018). Although this idea is still under debate and there is no consensus yet (Rainard et al., 2018), LP could be a potential additional trait for inclusion in udder health indexes along with SCC/ SCS. Breeding for LP makes sense in this perspective. As reported by Martin et al. (2018), the addition of new traits such as LP in selection indexes will improve the EBV accuracy and allow for faster genetic improvement of traits of interest, such as mastitis resistance, udder health, and energy balance in future generations of dairy cows. However, reliable estimations of proper weights and economic values through population-level simulations are required. Economic values for LP and LY should be developed, taking into account specific objectives, dairy outputs, processing costs, and market prices, adapting and updating the model proposed by Garrick and Lopez-Villalobos (2000) in the desired directions. In New Zealand, Sneddon et al. (2016) estimated the correlated responses in LY, LP, and protein-to-protein-plus-lactose ratio following selection for breeding worth, breeding worth plus LY, breeding worth plus LP, and breeding worth plus protein-to-protein-pluslactose ratio. The reason for these selection indexes was to evaluate whether cows might produce milk with the right protein-to-protein-plus-lactose ratio: that is a more suitable milk composition for the production of whole milk powder. Those authors concluded that the New Zealand dairy industry could reduce the import of foreign lactose by 6 to $11 \%$ per ton of whole milk powder by including lactose in the breeding objective, if compared with selection on solely breeding worth. However, before a new trait is included in any selection index for specific breeding goals, an evaluation of the potential pleiotropic effects is essential; therefore, further phenotypic and genetic investigations of LP and LY are required. In the era of big data, modern hi-tech milking systems can provide daily information about milk from individual cows; this would allow for a better understanding of the phenotypic and genetic "behavior" of milk lactose within and across lactations.

\section{ACKNOWLEDGMENTS}

This study was supported by the University of Padova (Ricerca Scientifica fondi DOR-2017, project DOR1721792/17, Italy). All authors actively contributed to the discussion of the results, commented on the manuscript, reviewed the paper, and approved the final version.

\section{REFERENCES}

Alessio, D. R. M., A. T. Neto, J. P. Velho, I. B. Pereira, D. J. Miquelluti, D. A. Knob, and C. G. da Silva. 2016. Multivariate analysis of lactose content in milk of Holstein and Jersey cows. Semina Ciênc. Agrár. 37:2641-2652. https://doi.org/10.5433/1679 -0359.2016v37n4Supl1p2641.

Atkinson, A. J., W. A. Colburn, V. G. DeGruttola, D. L. DeMets, G. J. Downing, D. F. Hoth, J. A. Oates, C. C. Peck, R. T. Schooley, B. A. Spilker, J. Woodcock, and S. L. Zeger. 2001. Biomarkers and surrogate endpoints: Preferred definitions and conceptual framework. Clin. Pharmacol. Ther. 69:89-95. https://doi.org/10.1067/ mcp.2001.113989 
Bansal, B. K., J. Hamann, N. T. Grabowski, and K. B. Singh. 2005. Variation in the composition of selected milk fraction samples from healthy and mastitic quarters, and its significance for mastitis diagnosis. J. Dairy Res. 72:144-152. https://doi.org/10.1017/ S0022029905000798.

Bastin, C., L. Théron, A. Lainé, and N. Gengler. 2016. On the role of mid-infrared predicted phenotypes in fertility and health dairy breeding programs. J. Dairy Sci. 99:4080-4094. https://doi.org/10 $.3168 /$ jds.2015-10087.

Bauman, D. E., and W. B. Currie. 1980. Partitioning of nutrients during pregnancy and lactation: A review of mechanisms involving homeostasis and homeorhesis. J. Dairy Sci. 63:1514-1529. https:// doi.org/10.3168/jds.S0022-0302(80)83111-0.

Beerda, B., W. Ouweltjes, L. B. J. Šebek, J. J. Windig, and R. F. Veerkamp. 2007. Effects of genotype by environment interactions on milk yield, energy balance, and protein balance. J. Dairy Sci. 90:219-228. https://doi.org/10.3168/jds.S0022-0302(07)72623-1.

Belay, T. K., M. Svendsen, Z. M. Kowalski, and T. Ádnøy. 2017. Genetic parameters of blood $\beta$-hydroxybutyrate predicted from milk infrared spectra and clinical ketosis, and their associations with milk production traits in Norwegian Red cows. J. Dairy Sci. 100:6298-6311. https://doi.org/10.3168/jds.2016-12458.

Bobbo, T., P. L. Ruegg, G. Stocco, E. Fiore, M. Gianesella, M. Morgante, D. Pasotto, G. Bittante, and A. Cecchinato. 2017. Associations between pathogen-specific cases of subclinical mastitis and milk yield, quality, protein composition, and cheese-making traits in dairy cows. J. Dairy Sci. 100:4868-4883. https://doi.org/10 $.3168 /$ jds.2016-12353

Cant, J. P., D. R. Trout, F. Qiao, and N. G. Purdie. 2002. Milk synthetic response of the bovine mammary gland to an increase in the local concentration of arterial glucose. J. Dairy Sci. 85:494-503. https://doi.org/10.3168/jds.S0022-0302(02)74100-3.

Chang, H. H., and A. K. Mishra. 2011. Does the milk income loss contract program improve the technical efficiency of US dairy farms? J. Dairy Sci. 94:2945-2951. https://doi.org/10.3168/jds.2010-4013.

Cinar, M., U. Serbester, A. Ceyhan, and M. Gorgulu. 2015. Effect of somatic cell count on milk yield and composition of first and second lactation dairy cows. Ital. J. Anim. Sci. 14:105-108. https:// doi.org/10.4081/ijas.2015.3646.

CLAL. 2018. Italy: Import/export summary. Accessed Mar. 18, 2018. https://www.clal.it/en/?section=quadro_italia.

Costa, A., C. Egger-Danner, G. Mészáros, C. Fuerst, M. Penasa, J. Sölkner, and B. Fuerst-Waltl. 2019. Genetic associations of lactose and its ratios to other milk solids with health traits in Austrian Fleckvieh cows. J. Dairy Sci. 102:4238-4248. https://doi.org/10 $.3168 /$ jds.2018-15883.

Costa, A., N. Lopez-Villalobos, G. Visentin, M. De Marchi, M. Cassandro, and M. Penasa. 2018. Heritability and repeatability of milk lactose and its relationships with traditional milk traits, somatic cell score and freezing point in Holstein cows. Animal 13:909-916. https://doi.org/10.1017/S1751731118002094.

Dairy Farmers of Ontario. 2018. Producer milk prices. Accessed Jul. 7, 2018. http://www.milk.org/Corporate/Producers/PrdMilkPrices .aspx.

Dairygold Co-operative Society Ltd. 2011. Milk purchasing; terms and conditions. Accessed Apr. 26, 2018. http://www.dairygold.ie./ files/MC_1117_Keat_Milk_Purch_2001_A4_v13.pdf.

de Haas, Y. 2003. Somatic cell count patterns. PhD thesis. Wageningen University and Research, Wageningen, the Netherlands. Accessed Jan. 29, 2019. https://edepot.wur.nl/121462.

De Marchi, M., V. Toffanin, M. Cassandro, and M. Penasa. 2014 Invited review: Mid-infrared spectroscopy as phenotyping tool for milk traits. J. Dairy Sci. 97:1171-1186. https://doi.org/10.3168/ jds.2013-6799.

Domínguez-Jiménez, J. L., and A. Fernández-Suárez. 2017. Diagnosis of lactose intolerance. Med. Clin. (Barc.) 148:262-264. https://doi .org/10.1016/j.medcli.2016.11.018.

Ebrahimie, E., F. Ebrahimi, M. Ebrahimi, S. Tomlinson, and K. R. Petrovski. 2018. A large-scale study of indicators of sub-clinical mastitis in dairy cattle by attribute weighting analysis of milk composition features: highlighting the predictive power of lactose and electrical conductivity. J. Dairy Res. 85:193-200. https://doi .org/10.1017/S0022029918000249.

Ederer, S., C. Egger-Danner, W. Zollitsch, and B. Fuerst-Waltl. 2014. Metabolic disorders and their relationships to milk production traits in Austrian Fleckvieh. Proc. 39th Int. Committee for Animal Recording (ICAR) Mtg., Berlin, Germany. Accessed Apr. 25, 2018. https://www.icar.org/wp-content/uploads/2016/07/Metabolic -disorders-and-their-relationships-to-milk-production-traits-in.pdf.

Egger-Danner, C., J. B. Cole, J. E. Pryce, N. Gengler, B. Heringstad, A. Bradley, and K. F. Stock. 2015. Invited review: Overview of new traits and phenotyping strategies in dairy cattle with a focus on functional traits. Animal 9:191-207. https://doi.org/10.1017/ S1751731114002614.

El-Salam, M. H. A., and S. El-Shibiny. 2011. A comprehensive review on the composition and properties of buffalo milk. Dairy Sci. Technol. 91:663-699. https://doi.org/10.1007/s13594-011-0029-2.

Forsbäck, L., H. Lindmark-Månsson, A. Andrén, and K. SvennerstenSjaunja. 2010. Evaluation of quality changes in udder quarter milk from cows with low-to-moderate somatic cell counts. Animal 4:617-626. https://doi.org/10.1017/S1751731109991467.

Fox, P. F., T. Uniacke-Lowe, P. L. H. McSweeney, and J. A. O'Mahoni. 2015. Dairy Chemistry and Biochemistry. Springer International Publishing, Basel, Switzerland. https://doi.org/10.1007/978-3-319 $-14892-2$

FrieslandCampina. 2018. Milk price explained. Accessed Jul. 7, 2018 https://www.frieslandcampina.com/en/organisation/financials/ milk-price-explained/.

García-Ochoa, F., V. E. Santos, J. A. Casas, and E. Gómez. 2000. Xanthan gum: Production, recovery, and properties. Biotechnol. Adv. 18:549-579. https://doi.org/10.1016/S0734-9750(00)00050-1.

Garrick, D. J., and N. Lopez-Villalobos. 2000. Potential for economic benefits to the producer from altering the composition of milk. BSAP Occasional Publication 25:93-108. https://doi.org/10.1017/ S1463981500040681.

Geary, U., N. Lopez-Villalobos, D. J. Garrick, and L. Shalloo. 2010. Development and application of a processing model for the Irish dairy industry. J. Dairy Sci. 93:5091-5100. https://doi.org/10 $.3168 /$ jds.2010-3487.

Geary, U., N. Lopez-Villalobos, B. O'Brien, D. J. Garrick, and L. Shalloo. 2014. Estimating the impact of somatic cell count on the value of milk utilising parameters obtained from the published literature. J. Dairy Res. 81:223-232. https://doi.org/10.1017/ S0022029914000053.

Geuss, J. 2013. Class III milk price suffers as US cheese, butter stocks remain high. Accessed Jul. 7, 2018. https://www.dairyreporter .com/Article/2013/08/06/Class-III-milk-price-suffers-as-US -cheese-butter-stocks-remain-high.

Gillon, A., C. Bastin, H. Soyeurt, and N. Gengler. 2010. Genetic parameters of mastitis-correlated milk components in first parity dairy cows. Page 27 in Proc. 9th World Congress on Genetics Applied to Livestock Production, Leipzig, Germany. Accessed Apr. 20, 2018. https://orbi.uliege.be/handle/2268/69459.

Glanbiaconnect. 2016. Milk lactose levels are a key indicator. Accessed Jun. 12, 2018. https://www.glanbiaconnect.com/farm -management/detail/all/milk-lactose-levels-are-a-key-indicator

Global Dairy Trade. 2018. Lactose. Accessed Jul. 30, 2018. https:// www.globaldairytrade.info/en/product-results/lactose/.

Gottardo, P., M. Penasa, F. Righi, N. Lopez-Villalobos, M. Cassandro, and M. De Marchi. 2017. Fatty acid composition of milk from Holstein-Friesian, Brown Swiss, Simmental and Alpine Grey cows predicted by mid-infrared spectroscopy. Ital. J. Anim. Sci. 16:380389. https://doi.org/10.1080/1828051X.2017.1298411.

Haile-Mariam, M., and J. E. Pryce. 2017. Genetic parameters for lactose and its correlation with other milk production traits and fitness traits in pasture-based production systems. J. Dairy Sci. 100:3754-3766. https://doi.org/10.3168/jds.2016-11952.

Harmon, R. J. 1994. Physiology of mastitis and factors affecting somatic cell counts. J. Dairy Sci. 77:2103-2112. https://doi.org/10 .3168/jds.S0022-0302(94)77153-8.

Herve, L., V. Lollivier, H. Quesnel, and M. Boutinaud. 2018. Oxytocin induces mammary epithelium disruption and could stimu- 
late epithelial cell exfoliation. J. Mammary Gland Biol. Neoplasia 23:139-147. https://doi.org/10.1007/s10911-018-9400-8.

Holmes, C. W., I. M. Brookes, D. J. Garrick, D. D. S. Mackenzie, T. J. Parkinson, and G. F. Wilson. 2007. Milk Production From Pasture. Principles and Practices. Massey University, Palmerston North, New Zealand.

Hossein-Zadeh, N. G., and M. Ardalan. 2011. Estimation of genetic parameters for milk urea nitrogen and its relationship with milk constituents in Iranian Holsteins. Livest. Sci. 135:274-281. https:/ /doi.org/10.1016/j.livsci.2010.07.020.

IDF (International Dairy Federation). 2006. Payment systems for exfarm milk. Bulletin of the International Dairy Federation 403/2006. IDF, Brussels, Belgium.

Interbull. 2018. National genetic evaluation forms provided by countries. Accessed Sep. 5, 2018. http://www.interbull.org/ib/geforms

ISO (International Organization for Standardization). 2007. 22662. Milk and milk products-Determination of lactose content by high-performance liquid chromatography (reference method). ISO, Geneva, Switzerland.

ISO (International Organization for Standardization). 2010. 26462. Milk-Determination of lactose content - enzymatic method using difference in $\mathrm{pH}$. ISO, Geneva, Switzerland.

Jesse, E. V., and R. A. Cropp. 2004. Basic milk pricing concepts for dairy farmers. Bulletin A3379. University of Wisconsin Co-operative Extension, Madison, WI.

Kester, H. J., D. E. Sorter, and J. S. Hogan. 2015. Activity and milk compositional changes following experimentally induced Streptococcus uberis bovine mastitis. J. Dairy Sci. 98:999-1004. https:// doi.org/10.3168/jds.2014-8576.

Koeck, A., B. Heringstad, C. Egger-Danner, C. Fuerst, P. Winter, and B. Fuerst-Waltl. 2010. Genetic analysis of clinical mastitis and somatic cell count traits in Austrian Fleckvieh cows. J. Dairy Sci. 93:5987-5995. https://doi.org/10.3168/jds.2010-3451.

Ladd, G. W., and J. R. Dunn. 1979. Estimating values of milk components to a dairy manufacturer. J. Dairy Sci. 62:1705-1712. https:/ /doi.org/10.3168/jds.S0022-0302(79)83486-4.

Larsen, T., and K. M. Moyes. 2015. Are free glucose and glucose-6-phosphate in milk indicators of specific physiological states in the cow? Animal 9:86-93. https://doi.org/10.1017/S1751731114002043.

Lemosquet, S., E. Delamaire, H. Lapierre, J. W. Blum, and J. L. Peyraud. 2009. Effects of glucose, propionic acid, and nonessential amino acids on glucose metabolism and milk yield in Holstein dairy cows. J. Dairy Sci. 92:3244-3257. https://doi.org/10.3168/ jds.2008-1610.

Leonardi, M., P. Gerbault, M. G. Thomas, and J. Burger. 2012. The evolution of lactase persistence in Europe. A synthesis of archaeological and genetic evidence. Int. Dairy J. 22:88-97. https://doi .org/10.1016/j.idairyj.2011.10.010.

Loker, S., C. Bastin, F. Miglior, A. Sewalem, L. R. Schaeffer, J. Jamrozik, A. Ali, and V. Osborne. 2012. Genetic and environmental relationships between body condition score and milk production traits in Canadian Holsteins. J. Dairy Sci. 95:410-419. https://doi .org/10.3168/jds.2011-4497.

Lopdell, T. J., K. Tiplady, M. Struchalin, T. J. Johnson, M. Keehan, R. Sherlock, C. Couldrey, S. R. Davis, R. G. Snell, R. J. Spelman, and M. D. Littlejohn. 2017. DNA and RNA-sequence based GWAS highlights membrane-transport genes as key modulators of milk lactose content. BMC Genomics 18:968. https://doi.org/10.1186/ s12864-017-4320-3.

Løvendahl, P., and M. Riis Weisbjerg. 2017. Lactose in milk - how can lactose concentration data be beneficial in management and breeding? Proc. 41st Int. Committee for Animal Recording (ICAR) Meeting, Edinburgh, United Kingdom. Accessed Jan. 12, 2018. https://www.icar.org/Documents/technical_series/ICAR -Technical-Series-no-22-Edinburgh/Lovendahl.pdf.

Malchiodi, F., A. Cecchinato, M. Penasa, C. Cipolat-Gotet, and G. Bittante. 2014. Milk quality, coagulation properties, and curd firmness modeling of purebred Holsteins and first- and secondgeneration crossbred cows from Swedish Red, Montbéliarde, and Brown Swiss bulls. J. Dairy Sci. 97:4530-4541. https://doi.org/10 .3168/jds.2013-7868.
Malek dos Reis, C. B., J. R. Barreiro, L. Mestieri, M. A. de Felício Porcionato, and M. V. dos Santos. 2013. Effect of somatic cell count and mastitis pathogens on milk composition in Gyr cows. BMC Vet. Res. 9:67. https://doi.org/10.1186/1746-6148-9-67.

Martelli, G., P. Parisini, R. Scipioni, E. Cessi, and L. Sardi. 2002. The effects of pressed sugar beet pulp silage (PBPS) and dairy whey on heavy pig production. Ital. J. Anim. Sci. 1:25-33. https://doi .org/10.4081/ijas.2002.25.

Martin, P., H. W. Barkema, L. F. Brito, S. G. Narayana, and F. Miglior. 2018. Symposium review: Novel strategies to genetically improve mastitis resistance in dairy cattle. J. Dairy Sci. 101:27242736. https://doi.org/10.3168/jds.2017-13554.

McCain, H. R., S. Kaliappan, and M. A. Drake. 2018. Invited review: Sugar reduction in dairy products. J. Dairy Sci. 101:8619-8640. https://doi.org/10.3168/jds.2017-14347.

Miglior, F., A. Sewalem, J. Jamrozik, J. Bohmanova, D. M. Lefebvre, and R. K. Moore. 2007. Genetic analysis of milk urea nitrogen and lactose and their relationships with other production traits in Canadian Holstein cattle. J. Dairy Sci. 90:2468-2479. https://doi .org/10.3168/jds.2006-487.

Miglior, F., A. Sewalem, J. Jamrozik, D. M. Lefebvre, and R. K. Moore. 2006. Analysis of milk urea nitrogen and lactose and their effect on longevity in Canadian dairy cattle. J. Dairy Sci. 89:48864894. https://doi.org/10.3168/jds.S0022-0302(06)72537-1.

Moyes, K. M., T. Larsen, P. Sørensen, and K. L. Ingvartsen. 2014 Changes in various metabolic parameters in blood and milk during experimental Escherichia coli mastitis for primiparous Holstein dairy cows during early lactation. J. Anim. Sci. Biotechnol. 5:47. https://doi.org/10.1186/2049-1891-5-47.

Mrode, R. A., G. J. T. Swanson, and M. S. Winters. 1998. Genetic parameters and evaluations for somatic cell counts and its relationship with production and type traits in some dairy breeds in the United Kingdom. Anim. Sci. 66:569-576. https://doi.org/10 .1017/S1357729800009140.

Murad, H. A., H. S. H. Mohamed, and A. G. Abu-El-Khair. 2017. Impact of amino acids, nitrogen source and buffering system on xanthan yield produced on hydrolyzed whey lactose. Biotechnology (Faisalabad) 16:69-76. https://doi.org/10.3923/biotech.2017 .69 .76 .

Nasr, M. A., and M. S. El-Tarabany. 2017. Impact of three THI levels on somatic cell count, milk yield and composition of multiparous Holstein cows in a subtropical region. J. Therm. Biol. 64:73-77. https://doi.org/10.1016/j.jtherbio.2017.01.004.

NCBI (National Center for Biotechnology Information). 2018. LCT lactase. Accessed Jun. 16, 2018. https://www.ncbi.nlm.nih.gov/ gene?Cmd=DetailsSearch\&Term $=3938$.

Niknezhad, S. V., M. A. Asadollahi, A. Zamani, D Biria, and M. Doostmohammadi. 2015. Optimization of xanthan gum production using cheese whey and response surface methodology. Food Sci. Biotechnol. 24:453-460. https://doi.org/10.1007/s10068-015 -0060-9.

Osorio, J. S., J. Lohakare, and M. Bionaz. 2016. Biosynthesis of milk fat, protein, and lactose: Roles of transcriptional and posttranscriptional regulation. Physiol. Genomics 48:231-256. https://doi .org/10.1152/physiolgenomics.00016.2015.

Ouweltjes, W., B. Beerda, J. J. Windig, M. P. L. Calus, and R. F. Veerkamp. 2007. Effects of management and genetics on udder health and milk composition in dairy cows. J. Dairy Sci. 90:229 238. https://doi.org/10.3168/jds.S0022-0302(07)72624-3.

Penasa, M., M. De Marchi, and M. Cassandro. 2016. Short communication: Effects of pregnancy on milk yield, composition traits, and coagulation properties of Holstein cows. J. Dairy Sci. 99:48644869. https://doi.org/10.3168/jds.2015-10168.

Prazeres, A. R., F. Carvalho, and J. Rivas. 2012. Cheese whey management: A review. J. Environ. Manage. 110:48-68. https://doi .org/10.1016/j.jenvman.2012.05.018.

Pryce, J. E., K. L. Parker Gaddis, A. Koeck, C. Bastin, M. Abdelsayed, N. Gengler, F. Miglior, B. Heringstad, C. Egger-Danner, K. F. Stock, A. J. Bradley, and J. B. Cole. 2016. Invited review: Opportunities for genetic improvement of metabolic diseases. J. Dairy Sci. 99:6855-6873. https://doi.org/10.3168/jds.2016-10854. 
Ptak, E., P. Brzozowski, and J. Bieniek. 2012. Genetic parameters for lactose percentage in the milk of Polish Holstein-Friesians. J Anim. Feed Sci. 21:251-262. https://doi.org/10.22358/jafs/66072/ 2012.

Pyörälä, S. 2003. Indicators of inflammation in the diagnosis of mastitis. Vet. Res. 34:565-578. https://doi.org/10.1051/vetres:2003026.

Rainard, P., G. Fourcas, D. Boichard, and R. Rupp. 2018. Invited review: Low milk somatic cell count and susceptibility to mastitis. J. Dairy Sci. 101:6703-6714. https://doi.org/10.3168/jds.2018-14593.

Reist, M., D. Erdin, D. von Euw, K. Tschuemperlin, H. Leuenberger, Y. Chilliard, H. M. Hammon, C. Morel, C. Philipona, Y. Zbinden, N. Kuenzi, and J. W. Blum. 2002. Estimation of energy balance at the individual and herd level using blood and milk traits in highyielding dairy cows. J. Dairy Sci. 85:3314-3327. https://doi.org/10 .3168/jds.S0022-0302(02)74420-2.

Rigout, S., S. Lemosquet, J. E. van Eys, J. W. Blum, and H. Rulquin. 2002. Duodenal glucose increases glucose fluxes and lactose synthesis in grass silage-fed dairy cows. J. Dairy Sci. 85:595-606. https://doi.org/10.3168/jds.S0022-0302(02)74113-1.

Rzewuska, K., and T. Strabel. 2013. Genetic parameters for milk urea concentration and milk traits in Polish Holstein-Friesian cows. J. Appl. Genet. 54:473-482. https://doi.org/10.1007/s13353-013 $-0159-8$.

Samoré, A. B., R. Rizzi, A. Rossoni, and A. Bagnato. 2010. Genetic parameters for functional longevity, type traits, somatic cell scores, milk flow and production in the Italian Brown Swiss. Ital. J. Anim. Sci. 9:145-152. https://doi.org/10.4081/ijas.2010.e28.

Satoła, A., E. Ptak, A. Otwinowska-Mindur, and W. Jagusiak. 2017. Genetic parameters for lactose percentage and urea concentration in milk of Polish Holstein-Friesian cows. Anim. Sci. Pap. Rep. 35:159-172.

Sneddon, N. W., N. Lopez-Villalobos, S. R. Davis, R. E. Hickson, and L. Shalloo. 2015. Genetic parameters for milk components including lactose from test day records in the New Zealand dairy herd. N. Z. J. Agric. Res. 58:97-107. https://doi.org/10.1080/00288233 2014.978482

Sneddon, N. W., N. Lopez-Villalobos, S. R. Davis, R. E. Hickson, L. Shalloo, D. J. Garrick, and U. Geary. 2016. Responses in lactose yield, lactose percentage and protein-to-protein-plus-lactose ratio from index selection in New Zealand dairy cattle. N. Z. J. Agric Res. 59:90-105. https://doi.org/10.1080/00288233.2015.1131724.

Sneddon, N. W., N. Lopez-Villalobos, R. E. Hickson, and L. Shalloo. 2012. Genetic parameters for lactose and its relationship with concentrations and ratios of other milk components. Proc. N.Z. Soc. Anim. Prod. 72:76-80. Accessed Jan. 12, 2017. http://www.nzsap .org/system/files/proceedings/2012/ab12018.pdf.
Sneddon, N. W., N. Lopez-Villalobos, R. E. Hickson, and L. Shalloo 2013. Review of milk payment systems to identify the component value of lactose. Proc. N.Z. Soc. Anim. Prod. 73:33-36. Accessed Jan. 18, 2017. http://www.sciquest.org.nz/elibrary/download/ 142565/Review_of_milk_payment_systems_to_identify_the_com .pdf.

Stoop, W. M., H. Bovenhuis, and J. A. M. van Arendonk. 2007. Genetic parameters for milk urea nitrogen in relation to milk production traits. J. Dairy Sci. 90:1981-1986. https://doi.org/10.3168/ jds.2006-434.

Sturaro, A., M. Penasa, M. Cassandro, A. Varotto, and M. De Marchi. 2014. Effect of microparticulated whey proteins on milk coagulation properties. J. Dairy Sci. 97:6729-6736. https://doi.org/10 $.3168 /$ jds.2014-8157.

Tiezzi, F., D. Pretto, M. De Marchi, M. Penasa, and M. Cassandro. 2013. Heritability and repeatability of milk coagulation properties predicted by mid-infrared spectroscopy during routine data recording, and their relationships with milk yield and quality traits. Animal 7:1592-1599. https://doi.org/10.1017/S1751731113001195.

Tyrrell, H. F., and J. T. Reid. 1965. Prediction of the energy value of cow's milk. J. Dairy Sci. 48:1215-1223. https://doi.org/10.3168/ jds.S0022-0302(65)88430-2.

Vilas Boas, D. F., A. E. Vercesi Filho, M. A. Pereira, L. C. Roma Junior., and L. El Faro. 2017. Association between electrical conductivity and milk production traits in Dairy Gyr cows. J. Appl. Anim. Res. 45:227-233. https://doi.org/10.1080/09712119.2016 .1150849 .

Visentin, G., S. McParland, M. De Marchi, A. McDermott, M. A. Fenelon, M. Penasa, and D. P. Berry. 2017. Processing characteristics of dairy cow milk are moderately heritable. J. Dairy Sci. 100:6343-6355. https://doi.org/10.3168/jds.2017-12642.

Wang, Q., and H. Bovenhuis. 2018. Genome-wide association study for milk infrared wavenumbers. J. Dairy Sci. 101:2260-2272. https:/ doi.org/10.3168/jds.2017-13457.

Wickramasinghe, S., S. Hua, G. Rincon, A. Islas-Trejo, J. B. German, C. B. Lebrilla, and J. F. Medrano. 2011. Transcriptome profiling of bovine milk oligosaccharide metabolism genes using RNAsequencing. PLoS One 6:e18895. https://doi.org/10.1371/journal .pone.0018895.

Xue, B., T. Yan, C. F. Ferris, and C. S. Mayne. 2011. Milk production and energy efficiency of Holstein and Jersey-Holstein crossbred dairy cows offered diets containing grass silage. J. Dairy Sci. 94:1455-1464. https://doi.org/10.3168/jds.2010-3663.

Zhao, F. Q. 2014. Biology of glucose transport in the mammary gland. J. Mammary Gland Biol. Neoplasia 19:3-17. https://doi.org/10 .1007/s10911-013-9310-8. 